\title{
Management of Large Size Wartsasia
}

\author{
Bakulesh Khamar* \\ Research and Development department, India
}

Received: March 09, 2018; Published: April 30, 2018

*Corresponding author: Bakulesh Khamar, Research and Development department, Cadila Pharmaceuticals Limited, Ahmadabad, India, Tel: 00912718-225001; Fax: 0091-2718-225031, Email: bmk@cadilapharma.co.in

Abstract

Large warts are difficult to treat as they need repeated treatment for a longer duration compared to small warts. They are associated with higher viral load and significantly more cell mediated immune suppression. There are no standardized guidelines for management of large warts. Intralesional immunotherapy like Candida antigen, Cadi-05 and antiviral like Cidofovir are found to be useful in achieving complete remission as a monotherapy and can be tried as first line treatment. Quadrilateral HPV vaccine is also useful in achieving complete remission as a first line therapy. Combination of ablation therapy and topical therapy may be useful in quicker resolution of mass and achieving complete resolution.

Keywords: Wart; Large wart; Immunomodulators; Combination therapy; Immune profile; Cidofovir; Immunosuppressant; Surgery

Abbreviations: HPV: Human Papilloma Virus (HPV), HIV: Human Immunodeficiency Virus (HIV), PD-1: Programmed Cell Death Protein 1, RR: Risk Ratio, IFN: Interferon, CI: Confidence Interval, PDL: Pulsed Dye Lasers, NSCLC: Non-Small Cell Lung Cancer, PDT: Photo Dynamic Therapy (PDT), TNF: Tumor Necrosis Factor

\section{Introduction}

Warts are caused by the Human Papilloma Virus (HPV) mainly by low risk HPV. Human papilloma viruses (HPVs) essentially induce skin and mucosal epithelial lesions [1-3]. Immune compromised individuals are more prone to HPV infection. HPV infection is almost six times more common in patients with human immunodeficiency virus (HIV) [4,5]. Low-risk HPV types behaving more aggressively in immune compromised patients [4]. Each HPV type is typically associated with infections of specific areas (location) on the body and induces distinct histological lesion [6-9].

\section{Common warts (verruca vulgaris)}

HPV types 2 and 4 (most common); also types 1, 3, 26, 29, and 57 and others. Clinically they appear as slightly raised rough surface epithelial proliferations. They are most often seen on hands but can grow anywhere on the body.

\section{Flat warts (verruca plana)}

HPV types 3,10, 28, 38, and 49. Clinically they appear as a small (1-2mm), smooth flattened, skin colored wart [10]. They can occur in large numbers. They are most common on the face, neck, hands, wrists and lower part of legs but never in the soles of hands. Very rarely they assume large size. They usually regress and get cleared on their own within 2 months with resolution of infection.

\section{Plantar warts (verruca plantaris) (myrmecia)}

HPV type 1 (most common) also types 2, 3, 4, 27, 28, 58, 66 and others. A plantar wart is a wart occurring on the bottom of the foot or toes [11], usually on pressure points on the soles of the feet.

\section{Anogenital warts (condylomata, acuminata or venereal warts)}

HPV types 6, 11(most common), 16, 18, 42, 44 and also others; a wart that occurs on the genitalia, anal region. They can be confluent or large size.

\section{Butcher's warts of the hands and fingers (HPV 7)}

Butcher's wart is a cutaneous (skin) condition with a prevalence of $8.5 \%$ to $23.8 \%$ among butchers and other meat-handling professions $[12,13]$.

\section{Natural Course and Immune Profile}

Like majority of viral diseases almost $75 \%$ of warts regress spontaneously [8] with 30\% regressing within four months [14]. Rest persist, progress with increase in no. and size. Immune response to HPV infection is responsible for spontaneous regression of warts. Spontaneously regressing warts have epidermal and dermal influx of $\mathrm{CD}^{4+}$ activated memory lymphocytes, low level of Il-10, high level of Interferon and Th1 response $[4,15,16] . \mathrm{CD}^{4+v e}$ lymphocytes within the wart 
stoma and the surface epithelium [5] along with macrophage predominate $[2,17]$ in regressing wart. There is a significant change in the ratio of $\mathrm{CD}^{4+}$ to $\mathrm{CD}^{8+}$ cells [17].

The failure to develop effective cell-mediated immunity to clear or control infection is associated with systemic or local immune dysfunction or defects [18]. There is a down regulation of major histocompatibility complex I and II in local lesions, alternation of the ratio of $\mathrm{CD}^{4+}$ and $\mathrm{CD}^{8+} \mathrm{T}$ lymphocytes, decrease in expression of tumor necrosis factor (TNF) $\alpha$, GM CSF, interleukin (IL) $1 \alpha$ and IL $1 \beta$, increased expression of IL 10 , the dysfunction and decreased number of langerhans cells and expression defects of co stimulatory molecules $[4,8]$. There is a marked increase in Tregs expressing expression Foxp3, TGF $\beta 1$, IL 10, CTLA4, GITR and PD 1 [18,19]. Increase Tregs are induced by epithelial cell expressing E7 protein [20]. NK cell activity is suppressed due to reduction in expression of NKG2D and NKp46 [18]. There is a decreased ratio of Th1/Th2 and Tc1/Tc2 [19,21]. There is decrease in Th1 cytokine (IL 2, IL 12 and IFN $\gamma$ ) and increase in Th2 cytokines (IL 4 and IL 10) [18,21]. Persisting warts can be divided into small $(<5 \mathrm{~mm})$ medium $(5$ to $8 \mathrm{~mm})$ or large $(>8 \mathrm{~mm})$ as per size. Intralesional cell mediated immune suppression is proportionate to size of wart. FoxP3 expressing Treg cells (immune suppressive cells) are highest in large wart and absent in small warts [22]. This cell seems to be responsible for decreased expression of IFN and IL-2 and increased expression of IL-10 and TGF-beta in large wart compared to small warts [22].

\section{Response to Therapy and Immune Changes}

Like spontaneous regression, increased cell mediated immune response of Th1 type with infiltration of immune cells [16,23-34] are important for treatment induced regression of warts. There is no change in immune profile of non-responders/ per sisters. In spite of clearance with therapy, recurrence is seen in large no (25\%-67\%) within three months. Reactivation at the site of previous infection, and persistence following are believed to be responsible for recurrence [8]. Cell mediated immune suppression as revealed by decrease in Th1 cytokine and CD4 T cells, suppression of delayed type hypersensitivity and increase in 12. Programmed cell death protein 1(PD-1) expressing $\mathrm{T}$ cells is found in recurrent warts $[24,35,36]$. Predominant Th1 or mixed Th1/Th2 cytokine profile is seen in non- recurrent warts [24].

\section{Therapeutic Options}

Warts are superficial lesions harboring virus. One of the options is to get rid of tissues harboring viruses and include surgical removal, cryotherapy, laser therapy, pulsed laser therapy etc. as provider administered or office procedures. Uses of topical medications to be self-administered for removal of tissues include salicylic acid, podop etc. The other options include use of immune modulators to correct immune dysfunction for persistence of infection. Immunomodulators like imiquimod,
Sinecatechins are topical medications while isotretinoin, cyclophosphamide are oral medication for self-administrations. Immunomodulators can be administered intralesional as office procedure. Intralesional immune modulators include allergens (antigen) like candida used for determining dermal hypersensitivity, CADI-05. Quadrilateral HPV vaccine approved for prevention of HPV vaccine is also found useful in treatment of warts. Cidofovir is antiviral agent active against cytomegalovirus infection. It is found useful in management of warts when administered topically or intralesional.

With multiple options available, treatment in a given patient is determined by number, size, and location of lesions [2] and preference of a physician as well as patients. Large warts are difficult to treat due to their size and associated cell mediated immune suppression. The management may require repeated treatments over a prolonged time period [37]. Their size makes it difficult for topical therapies to achieve desired tissue concentrations. First-line treatment is not always successful in achieving complete clearance [37]. Current evidence is also not adequate to suggest best option for treatment of large warts [37]. CO2 laser therapy, are generally associated with higher probabilities of complete clearance at the end of treatment for large warts [37]. Very large wart lesions, including BuschkeLöwenstein tumors, can be considered for surgical treatment [37]. However surgical treatment is generally not recommended as first line therapy due to scar formation following it and or need for anesthesia and another specialist [37]. Review of literature suggests that some of the immunotherapeutic agents are useful in management of large wart as a monotherapy and include Candida antigen, CADI-05, Quadrivalent HPV vaccine. Of these, CADI-05 is found to have antiviral properties and viral load, as well. Cidofovir is also described as useful in management of large warts as a monotherapy.

Compared to smaller warts, large warts are associated with increased viral load and cell mediated immune suppression and so targeting both may be useful. This can be achieved by combining two or more therapeutic options. For decreasing viral load by removing tissue, cryotherapy, surgical excision/ debulking, Laser therapy, photodynamic therapy can be used. The advantage of these procedures is immediate decrease in viral load. Disadvantages include need for multiple treatment session for complete cure, high recurrence rate and scar formation. Cidofovir, an antiviral agent, can be administered topically or intralesional. For improving immune profile, Imiquimod, Sinecatechins, CADI-05, Quadrilateral HPV vaccine, cyclophosphamide are found useful. . Combination therapies described to be useful in management of large warts include ablative procedure like cryotherapy/ laser therapy with topical immunotherapy like Imiquimod, Sinecatechins. Ablative procedure is also combined with isotretinoin and cyclophosphamide. Combination of ablative procedure with antiviral cidofovir is also found useful. 


\section{Candida Antigen}

Sensitivity testing by intradermal injection of an antigen (allergen) is a measure of delayed cell mediated immunity. Candida antigen injection in patients sensitive to Candida antigen is associated with complete resolution of warts in $(54 \%$ $-76 \%$ ] of patients [38-43]. Clearance of distant untreated warts is seen in $(57 \%-78 \%)$ of patients [38-43]. Candida antigen is useful irrespective of size (small or large) or no. of warts [38-43]. It is effective in newly diagnosed warts as well as warts resistant to standard treatment in immune compromised individuals also [38-45]. Intradermal injection of Candida antigen up regulates the cell-mediated immune response, augmenting the overall clearance of the HPV [46].

The baseline immune status as determined by IFN-gamma levels seems to predict outcome with higher levels seen in responders [41]. The response is associated with HPV L1 peptide specific cell mediated immune response [47].

The recommended dosing regimen is $0.1-0.3 \mathrm{~mL}$ of Candida antigen injected intradermally into the largest lesion every two to three weeks until complete clearance of the wart or a maximum of three to five treatments $[39,41,42]$. Side effects include mild erythema and pain at the site of injection. There is one reported case of vitiligo and another case of painful, purple discoloration at the site of injection $[40,48,49]$. Like Candia antigen, other skin sensitizing agents used include mumps, trichophyton and tuberculin [50].

\section{CADI-05}

CADI-05 is a potent TLR 2 agonist which induces pure potent systemic Th1 response [51]. It induces prominent delayed hypersensitivity response by increasing innate as well as adaptive immune response [52-54]. Unlike other immunotherapy it decreases immunosuppressive $\mathrm{T}$ cells like Treg also [52,56]. Effect on immune suppression is significant and manifests as improved CD4 count in HIV positive individuals [55]. The systemic immune response generated is strong enough to work as monotherapy in bladder cancer [56] and melanoma [57]. It is approved for treatment of advanced Non-small cell lung cancer (NSCLC) along with chemotherapy in India.

In management of wart it is administered intradermally or intralesional or combination of two [58-66]. It generates systemic immune response following intralesional administration and clears remote (distant, non-injected) warts [61-63,65]. Its administration is associated with clearance of HPV virus also [64]. It achieves complete clearance in small as well as large warts, cutaneous as well as anogenital warts [58-66]. It is effective in newly diagnosed as well as recalcitrant wart which has not responded to other therapies or recurred following other therapies [58-62]. No. of administration for achieving complete response seems to be related to size and/or no. of warts [63]. New warts following clearance, if seen are at a different location [63].
Following therapy with CADI-05 of large refractory extragenital warts, complete clearance of treated warts was seen in $66.7 \%(20 / 30)$ of the patients with clearance of $46.2 \%$ of distant warts [61]. Complete clearance is also seen in large anogenital warts $[58,66]$. The reported systemic side effects include flu-like symptoms, fever, and lymphadenopathy $[60,62,63,65]$. Injection site reaction include pain, modularity, ulceration, scarring at the site of injection $[60,62,63,65]$.

\section{Quadrivalent HPV Vaccine}

Quadrivalent HPV vaccine, GARDASIL, is approved for prevention of diseases caused by HPV types 6,11,16,18. It is also found useful in management of wart as a therapeutic vaccine [67-76]. It induces complete clearance of chronic warts, warts not responding to other therapies irrespective of its size $[67,68,70-76]$. It works in immune compromised individuals also $[67,69,72,75]$. The decrease in size is evident following first injection. Complete clearance is achieved three months after third dose. Clearance of warts caused by other (not included in vaccine) e.g. HPV 2 type is also seen [68,72]. Surprisingly anogenital warts are not cleared while cutaneous warts are cleared following administration of quadrivalent vaccine [69].

The major drawback of quadrilateral vaccine is time required for administration of three dose (0,2 and 6 months) and time taken for complete resolution of warts. Quadrivalent vaccine is now replaced by nine talent vaccine providing prophylaxis against HPV type $31,33,45,52$, and 58 also. This should provide better efficacy than quadrilateral vaccine. It will be useful to evaluate it in recalcitrant large size warts.

\section{Cidofovir}

Cidofovir is approved for treatment of cytomegalovirus infection by intravenous route of administration $[77,78]$. Cidofovir has been shown to reduce E6 and E7 expression in HPV + ve cells and thereby reducing proliferation of infected cells leading to apoptosis, and virustatic control of HPV infection [78,79]. Cidofovir works on HPV transformed cells having compromised DNA repair [80]. It has no effect on normal cells. In animal studies of HPV infections, systemic administration is not found useful [81]. Topical treatment is useful in small/medium size lesions [81]. Intralesional cidofovir cures even large papilloma [81]. Recurrences following intralesional cidofovir can be eliminated by combining it with immunotherapy [82].

Topical and intralesional cidofovir has been successfully used in treatment of warts [78,79,83-93]. Best results with topical cidofovir are seen with $3 \%$ cidofovir applied twice daily. Treatment should be stopped if there is no response after 10 weeks [83]. It is found useful for warts on the oral mucosa, hands and anogenital region [84]. Complete response following topical cidofovir range from $47 \%-57.5 \%$ [94,95]. Complete response is also possible in a large wart a [83]. Female gender, younger age and genital warts are likely to have complete response following topical cidofovir [95]. 
The most common side effects of topical cidofovir are pain, pruritus and rash at the application site [96].

Intralesional cidofovir $7.5 \mathrm{mg}$ to $25 \mathrm{mg} / \mathrm{mL}$ is administered once a month $[84,91,92]$. This achieved complete wart clearance 276 of 280 patients $(98.5 \%)$ in recalcitrant warts with no recurrence [85]. Intralesional cidofovir is found useful in management of a large wart [92]. The most common adverse events with these injections were pain, burning sensation, itching, erythema, and post-inflammatory hyper pigmentation [85]. Topical cidofovir 3\% is found useful in management of large warts in immune compromised hosts with surgical debulking in anecdotal cases $[97,98]$.

\section{Cryotherapy}

Cryotherapy, an inexpensive and simple provider administered procedure using liquid nitrogen in a spray or cryoprobe. The temperatures involved with cryotherapy are cold to the point that there is permanent dermal and vascular damage leading to necrosis and clearance of the abnormal cells and is frequently used to destroy warts by cold-induced cytolysis. It does not treat subclinical lesions in the surrounding skin and can account for recurrence. A recent systematic review of randomized controlled trials (RCTs) on local treatments for immune competent and HIV infected patients globally concluded that ablative techniques are clinically more effective at completely clearing warts immediately.

(-Health assessment-) Cryotherapy is considered a firstline provider administered therapy due to its relative ease of administration and cost. Cryotherapy efficacy did not appear to differ from that of topical therapies [99-101] and is very effective for multiple and small warts [102]. Recurrence rates are estimated between $25 \%$ and $42 \%$ [102-105]. Combining it with interferon (IFN) - alpha does not improve clearance rate as well as recurrence rate [105] outcome. Electro surgery was weakly associated with better AGW clearance than cryotherapy (risk ratio (RR) 0.80, 95\% confidence interval (CI) 0.65-0.99) [100]. Cryotherapy is associated with more immediate adverse events (erythema, stinging, or irritation; RR 3.02, 95\% CI 1.38-6.61) and immediate pain requiring oral analgesics (RR 2.11, 95\% CI 1.07-4.17) [99,100,106]. Local tissue destruction with blistering, ulceration, infection, and loss of pigmentation manifest later. There is also a risk for permanent scarring [102]. Cryotherapy is not popular as a monotherapy in management of large warts as treatment of a widely involved area is not tolerated well by patients due to pain and multiple visits needed for complete clearance.

\section{Surgical Excision}

Warts may be removed surgically via shave excision, scissor excision, curettage, and/or electro cautery [102]. Surgical intervention provides immediate results, which is useful in patients with large, obstructive or extensive warts [102]. It also provides opportunity for histopathological assessment for lesions suspicious of malignancy. Recurrence following surgical excision is described in $19 \%$ to $29 \%$ of cases [107-109]. The high recurrence rates may be attributed to the clinically unapparent surrounding tissue that continues to harbor the HPV virus. Disadvantages include bleeding, longer healing course, and pain. It can be combined with other topical therapies to improve outcome. This is not the procedure of choice for majority of patients with large wart.

\section{Laser therapy}

\section{Carbon dioxide laser}

Carbon dioxide $\left(\mathrm{CO}^{2}\right)$ laser has been a valuable tool as a destructive therapy for genital warts that uses infrared light energy to vaporize targeted areas [110-112] to provide bloodless removal. Clearance rates range between $23 \%$ and $52 \%$ with recurrence rates as high as $77 \%$. HIV-negative patients responded better to treatment with a $71 \%$ cure rate versus $58 \%$ for HIV-positive patients. Scarring, hypo pigmentation, are some of the disfiguring adverse effects of $\mathrm{CO}^{2}$ laser treatment of warts $[113,114]$. Postoperative pain and prolonged wound healing are other complications $[113,114]$. Scarring has been reported in up to $61 \%$ of patients treated for recalcitrant warts and appeared unrelated to wart duration or location [113]. Immune suppressed patients are especially susceptible to scarring and delayed wound healing [115]. This can be combined with other therapies to improve the outcome. Its side effect profile is better than cryotherapy [100].

\section{Pulsed Dye Lasers}

Pulsed dye lasers (PDL) emit a wavelength from 585 to $595 \mathrm{~nm}$, consistent with a hemoglobin absorption peak. It is hypothesized that PDL destroys the characteristically dilated superficial capillaries that supply warts, thereby starving the epidermal cells that host viral molecules [116-118]. Furthermore, it has been suggested that PDL destroys the HPV virus itself as a result of the virus's heat-sensitive properties [116,119-121]. PDL therapy has been used to treat simple and recalcitrant common, palmar, plantar, and flat warts, with studies reporting remission rates ranging from $47 \%$ to $100 \%$ [116,117,120-127]. Palmar warts may have higher response rates than plantar warts (75\% palmar vs 20\% plantar [125]; $93 \%$ palmar vs $69 \%$ plantar) [126]. PDL can treat warts in cosmetically important area. PDL is combined with other modalities to improve outcome. In recalcitrant warts, PDL followed by intralesional bleomycin (0.5 IU/mL; median, $0.3 \mathrm{~mL} /$ wart) achieved $89 \%$ remission in recalcitrant hand warts [127] with $80 \%$ in an immune compromised patients. Adverse effects of PDL therapy include local pain during and after the procedure, bullae, crusting, scarring, and temporary pigment changes $[117,118,124]$. PDL has significantly fewer adverse effects than the CO2 laser [122]. Compared with cryotherapy, PDL has a lower incidence of pain and bulla formation [122]. It is found useful in management of large warts also as a monotherapy. 


\section{Photodynamic Therapy}

5-aminolevulinic acid is a photosensitive which accumulates in HPV-infected cells in greater quantities than in adjacent normal skin following topical application [28] and is used for destruction of tissue harboring HPV by phototoxic reaction in photodynamic therapy (PDT). There is a significant, up to 10 fold increase of interleukin (IL)-1 alpha and a 2.5-fold increase of tumor necrosis factor-alpha [128] following photodynamic therapy (PDT). Response to therapy is associated with increase in CD8+ cells [28,128], CD4+ cells [129], dendritic cells, and decrease in Treg cells [130] with achievement of normal Treg level by three weeks. 5-aminolevulinic acid can be injected into lesion to enhance penetration and increase its effectiveness e.g larger or thicker lesions [131,132].

The main advantages of PDT are a high degree of effectiveness and safety, a short recovery period, good cosmetic results and the ability to treat a large surface area with minimal scarring and low recurrence rate [133-140] irrespective of site of lesion in general complete clearance rates of 56\%-100\% in recalcitrant hand and foot warts have been reported [135]. The reported recurrence rates with PDT are best amongst all ablative procedures as a monotherapy. PDT has been proposed for treating refractory lesions and lesions that recur despite the correct administration of another treatment. However, ALA-PDT was not shown to be beneficial as an adjunctive treatment to ablation of condyloma acuminata with a CO2 laser [141]. The adverse effects, all local, include pain [142], a burning sensation, and erythema [143]. Photodynamic therapy is ls better than cryotherapy for wart clearance and adverse events [140].

\section{Imiquimod}

Imiquimod (an imidazoquinoline amine), is an immune response modifier licensed for the topical treatment of external genital and perianal warts. Imiquimod acts through a Tolllike receptor (TLR7) [144,145]. Treatment with Imiquimod $[32,34]$ activates cell mediated immune response of Th1 type as revealed by significant increases in mRNA for interferon (IFN)-alpha, IFN-gamma, 2'5' AS , TNF-alpha, CD4 and CD8. Imiquimod is associated $[33,146]$ with a decrease in HPV DNA and in mRNA expression. Wart clearance [33] following treatment with Imiquimod is associated with evidence of tissue production of interferon-alpha, -beta, and -gamma and tumor necrosis factor-alpha. A significant correlation between the presence of circulating, pre-existing HPV specific T lymphocytes and regression of HPV positive lesions has also been observed $[147,148]$.

In clinical studies, wart clearance has been reported in $35-68 \%$ of patients with treatment courses up to 16 weeks [144,145,149-155]. The reported clearance rates are higher in women than in men, and also women have a shorter median time to clearance than men. Clearance is seen between 8-12 weeks for small cutaneous warts [156]. Recurrence rates (6$26 \%$ ) after successful clearance are low $[144,145,151,152,155]$.
Erythema is often seen as a side effect with Imiquimod therapy [156] and sometimes appears to precede clinical resolution [50]. Occasionally severe inflammation is seen necessitating discontinuation of therapy [50]. Rare side effects include psoriasis form eruptions, mucosal ulcerations, hyper pigmentation $[157,158]$.

It is combined with other therapies like laser [159-162], cryo therapy [163] salicylic acid [163,164] to improve clearance rates and minimize recurrences it has been successfully used as a combination therapy in management of large warts [164].

\section{Sinecatechins}

Sinecatechins (Polyphenon E) Polyphenon E is a standardized extract of green tea leaves (Camellia sinensis). Sinecatechins inhibits proliferation of HPV infected cells and also induces apoptosis in vitro [165]. Sinecatechins use is associated decreased viral load in warts. The decreased viral load is associated with changes in genes involved in regulation of cell signaling, immune response and apoptosis processes [166-168]. Sinecatechins inhibits MMP-2, MMP-7, MMP-9; lipoxygenases and cyclooxygenases [COX-1, COX-2]); epidermal growth factor [169].

An ointment containing Sinecatechins at a concentration of $15 \%$ and $10 \%$ are available as approved products for the treatment of external anogenital wart. Both have similar results. The dosage is 3 applications daily for up to 16 weeks. Randomized controlled trials in patients of both sexes has shown overall lesion clearance rates of between $54 \%$ and $65 \%$ compared to an average clearance rate of $35 \%$ in placebo groups [170-174]. Recurrence rates were between $6 \%$ and $12 \%$ after 12 weeks of follow-up. The effect of this substance is not evident clinically until approximately the third week of treatment and becomes more apparent in the fourth to sixth weeks [170].

The most common undesirable effects $(80 \%)$ are local ones, particularly erythema and pruritus that begin to appear in the second or third week of treatment [170-173]. Although a large percentage of patients have adverse reactions, they are well tolerated. Inflammation, indicative of the drug's activity, arises from a local immune response mediated by pro-inflammatory cytokines. The incidence of local skin reactions has been reported to be higher in responders than nonresponders [171]. The efficacy in immune compromised individuals is not known. Recurrence rate $(6.5 \%)$ is identical to placebo group [173]. Use of Sinecatechins following cryotherapy for warts, improves response rate of cryotherapy [175]. Response rate can be as high as $96.3 \%$ with a recurrence rate of $7.4 \%$ [176]. The combination may be useful on management of large tumors.

\section{Isotretinoin}

Retinoic Acid suppresses transcription of HPV [177]. Oral isotretinoin is used successfully in management of warts as a single agent [178-181]. Oral low dose $(0.5 \mathrm{mg} /$ day) is also useful [182-184]. Complete clearance is seen in $31.2 \%-100 \%$ 
[178,183-186]. Topical isotretinoin is not as effective as oral isotretinoin [181]. It can be combined with topical podophyllin for achieving complete response in partial responding/ recurring warts with topical podophyllin alone [187]. It is safe for use in immune compromised individuals $[179,188]$. It is found useful in treatment of large wart as a monotherapy seen in B-cell lymphoma following Rituximab [179]. It has been possible to achieve complete remission of large wart in immune compromised individual after surgical debulking [188]. Combining with interferon alpha does not seem to offer any additional advantage [186].

\section{Cyclophosphamide}

Large warts are associated with significant immune suppression via increased Treg cells and are believed to be responsible for partial response/recurrence following therapy. Oral cyclophosphamide (50mg/day for a week) is found useful in depleting Treg cells. Anecdotal case reports suggest its usefulness in achieving complete response as a standalone therapy for newly diagnosed and recurrent anogenital warts [189]. When used with laser therapy for large wart it helps in achieving and maintaining response. Recurrences are amenable to re-administration of oral cyclophosphamide [190]. This is achieved by altering milieu of lesion to normal.

\section{Conclusion}

Large warts are difficult to treat. There are no guidelines for its management. It is possible to achieve complete response with intralesional immunotherapy like Candida antigen, CADI-05 or antiviral Cidofovir. Quadrilateral HPV vaccine is also useful. Combination of ablation of lesion using various modalities with topical immunotherapy or antiviral is also useful.

\section{Conflict of Interest}

I have no conflict of interest since it is a review of published information. However, I am an employee of Cadila Pharmaceuticals limited who is a manufacturer of CADI-05.

\section{References}

1. de Villiers EM, Fauquet C, Broker TR, Bernard HU, Zur Hausen H (2004) Classification of papillomaviruses. Virology 324(1): 17-27.

2. Scheinfeld N, Lehman DS (2006) An evidence-based review of medical and surgical treatments of genital warts. Dermatol Online J 12(3): 5.

3. Cheah PL, Looi LM (1998) Biology and pathological associations of the human papillomaviruses: a review. Malays J Pathol 20(1): 1-10.

4. Sasagawa T, Takagi H, Makinoda S (2012) Immune responses against human papillomavirus (HPV) infection and evasion of host defense in cervical cancer. J Infect Chemother 18(6): 807-815.

5. Yamada R, Sasagawa T, Kirumbi LW, Kingoro A, Karanja DK, et al. (2008) Human papillomavirus infection and cervical abnormalities in Nairobi, Kenya, an area with a high prevalence of human immunodeficiency virus infection. J Med Virol 80(5): 847-855.

6. Mulhem E, Pinelis S (2011) Treatment of nongenital cutaneous warts. Am Fam Physician 84(3): 288-293.
7. Kodner CM, Nasraty S (2004) Management of genital warts. Am Fam Physician 70(12): 2335-2342.

8. Doorbar J, Quint W, Banks L, Bravo IG, Stoler M, et al. (2012) The biology and life-cycle of human papillomaviruses. Vaccine 30(Suppl 5): F55-F70.

9. Mui UN, Haley CT, Tyring SK (2017) Viral Oncology: Molecular Biology and Pathogenesis. J Clin Med.

10. Yoo H, Won SS, Choi HC, Yoon TJ, Ye SK, et al. (2005) Detection and identification of human papillomavirus types isolated from Korean patients with flat warts. Microbiol Immunol 49(7): 633-638.

11. Davis MD, Gostout BS, McGovern RM, Persing DH, Schut RL, et al. (2000) Large plantar wart caused by human papillomavirus-66 and resolution by topical cidofovir therapy. J Am Acad Dermatol 43(2 Pt 2): $340-343$.

12. Porro AM, Alchorne MM, Mota GR, Michalany N, Pignatari AC, et al. (2003) Detection and typing of human papillomavirus in cutaneous warts of patients infected with human immunodeficiency virus type 1 . Br J Dermatol 149(6): 1192-1199.

13. Majewski S, Jablonska S, Favre M, Orth G (2001) Human papillomavirus type 7 and butcher's warts. Arch Dermatol 137(12): 1655-1656.

14. Torres Poveda K, Bahena Román M, Madrid González C, Burguete García AI, Bermúdez Morales VH, et al. (2014) Role of IL-10 and TGF- $\beta 1$ in local immunosuppression in HPV-associated cervical neoplasia. World J Clin Oncol 5(4): 753-763.

15. Scott M, Stites DP, Moscicki AB (1999) Th1 cytokine patterns in cervical human papillomavirus infection. Clin Diagn Lab Immunol 6(5): 751755 .

16. Arany I, Evans T, Tyring SK (1998) Tissue specific HPV expression and down regulation of local immune responses in condylomas from HIV seropositive individuals. Sex Transm Infect 1998; 74(5): 349-353.

17. Coleman N, Birley HD, Renton AM, Hanna NF, Ryait BK, et al. (1994) Immunological events in regressing genital warts. Am J Clin Pathol 102(6): 768-774.

18. Shi YJ, Yang J, Yang W (2013) Mechanistic investigation of immunosuppression in patients with condyloma acuminata. Mol Med Rep 8(2): 480-486.

19. Xu Y, Zhu KJ, Zhu N, Jiang DH, Chen XZ, et al. (2009) Expression of Foxp3+CD4+CD25+ regulatory T cells and Th1/Th2, Tc1/Tc2 profiles in the peripheral blood of patients with condyloma acuminatum. Clin Exp Dermatol 34(2): 229-235.

20. Narayan S, Choyce A, Linedale R, Saunders NA, Dahler A, et al. (2009) Epithelial expression of human papillomavirus type 16 E7 protein results in peripheral CD8 T-cell suppression mediated by CD4+CD25+ T cells. Eur J Immunol 39(2): 481-490.

21. Li L, Zhou ZG, Zeng K, Liang LP, Zhou XY, et al. (2003) Changes in peripheral blood Th1/Th2 cell balance in patients with condyloma acuminatum. Di Yi Jun Yi Da Xue Xue Bao 23(7): 737-739.

22. Cao Y, Zhao J, Lei Z, Shen S, Liu C, et al. (2008) Local accumulation of FOXP3+ regulatory $\mathrm{T}$ cells: evidence for an immune evasion mechanism in patients with large condylomata acuminata. J Immunol 180(11): 7681-7686.

23. Arany I, Tyring SK (1996) Status of local cellular immunity in interferon-responsive and -nonresponsive human papillomavirusassociated lesions. Sex Transm Dis 23(6): 475-480.

24. Grassegger A, Rollinger Holzinger I, Zelger BW et al. (1997) Spontaneous or interferon-gamma-induced T-cell infiltration, HLA-DR and ICAM-1 expression in genitoanal warts are associated with TH1 or mixed TH1/TH2 cytokine mRNA expression profiles. Arch. Dermatol. Res. 289(5): 243-250. 
25. Resta L, Troia M, Russo S, Colucci GA, Sabatini R, et al. (1992) Variations of lymphocyte sub-populations in vulvar condylomata during therapy with beta-interferon. Eur J Gynaecol Oncol 13(5): 440-444.

26. Fierlbeck G, Schiebel U, Müller C (1989) Immuno histology of genital warts in different stages of regression after therapy with interferon gamma. Dermatologica 179(4): 191-195.

27. Arany I, Tyring SK (2009) Activation of local cell-mediated immunity in interferon-responsive patients with human papillomavirus-associated lesions. Journal of Interferon \& Cytokine Research 16(6): 453-460.

28. Abdel Hady ES, Martin Hirsch P, Duggan Keen M, Stern PL, Moore JV, et al. (2001) Immunological and viral factors associated with the response of vulval intraepithelial neoplasia to photodynamic therapy Cancer Res 61(1): 192-196.

29. Arany I, Tyring SK, Brysk MM, Stanley MA, Tomai MA, et al. (2000) Correlation between pretreatment levels of interferon response genes and clinical responses to an immune response modifier (Imiquimod) in genital warts. Antimicrobial Agents and Chemotherapy 44(7): 18691873.

30. Arany I, Brysk MM, Brysk H, Tyring SK (1996) Response to interferon treatment decreases with epidermal dedifferentiation in condylomas. Antiviral Res 32(1): 19-26.

31. Tyring SK, Cauda R, Ghanta V, Hiramoto R (1988) Activation of natural killer cell function during interferon-alpha treatment of patients with condyloma acuminatum is predictive of clinical response. J Biol Regul Homeost Agents 2(2): 63-66.

32. Arany I, Tyring SK, Stanley MA, Tomai MA, Miller RL, et al. (1999) Enhancement of the innate and cellular immune response in patients with genital warts treated with topical imiquimod cream $5 \%$. Antivira Res 43(1): 55-63.

33. Tyring SK, Arany I, Stanley MA, Tomai MA, Miller RL, et al. (1998) A randomized, controlled, molecular study of condylomata acuminata clearance during treatment with imiquimod. J Infect Dis 178(2): 551555

34. Tyring SK, Arany I, Stanley MA, Stoler MH, Tomai MA, et al. (1998) Mechanism of action of imiquimod $5 \%$ cream in the treatment of anogenital warts. Prim. Prim Care Update Ob Gyns 5(4): 151-152.

35. Chang DY, Song SH, You S, Lee J, Kim J, et al. (2014) Programmed death-1 (PD-1)-dependent functional impairment of CD4(+) T cells in recurrent genital papilloma. Clin Exp Med 14(3): 305-313.

36. Kyriakis KP, Balamotis AK, Katsarou Katsari A, Tosca AD (1995) Recurrent condylomata acuminata: how routine immediate and delayed hypersensitivity parameters might provide a clue to their immunopathogenesis. Eur J Clin Invest 25(12): 906-909.

37. Thurgar E, Barton S, Karner C, Edwards SJ (2016) Clinical effectiveness and cost-effectiveness of interventions for the treatment of anogenital warts: systematic review and economic evaluation. Health Technol Assess 20(24): v-vi, 1-486.

38. Majid I, Imran S (2013) Immunotherapy with intralesional Candida albicans antigen in resistant or recurrent warts: a study. Indian Dermatol 58(5): 360-365.

39. Johnson SM, Roberson PK, Horn TD (2001) Intralesional injection of mumps or Candida skin test antigens: a novel immunotherapy for warts. Arch Dermatol 137(4): 451-455.

40. Horn TD, Johnson SM, Helm RM, Roberson PK (2005) Intralesional immunotherapy of warts with mumps, Candida, and Trichophyton skin test antigens: a single-blinded, randomized, and controlled trial. Arch Dermatol 141(5): 589-594.

41. Nofal A, Marei A, Amer A, Amen H (2017) Significance of interferon gamma in the prediction of successful therapy of common warts by intralesional injection of Candida antigen. Int J Dermatol 56(10): 10031009.
42. Khozeimeh F, Jabbari Azad F, Mahboubi Oskouei Y, Jafari M, Tehranian $S$, et al. (2017) Intralesional immunotherapy compared to cryotherapy in the treatment of warts. Int J Dermatol 56(4): 474-478.

43. Muñoz Garza FZ, Roé Crespo E, Torres Pradilla M, Aguilera Peirò P, Baltà Cruz S, et al. (2015) Intralesional Candida Antigen Immunotherapy for the Treatment of Recalcitrant and Multiple Warts in Children. Pediatr Dermatol 32(6): 797-801.

44. Alikhan A, Griffin JR, Newman CC (2016) Use of Candida antigen injections for the treatment of verruca vulgaris: A two-year mayo clinic experience. J Dermatol Treat 27(4): 355-358.

45. Wong A, Crawford RI (2013) Intralesional Candida antigen for common warts in people with HIV. J Cutan Med Surg 17(5): 313-315.

46. Ramírez Fort MK, Au SC, Javed SA, Loo DS (2014) Management of cutaneous human papillomavirus infection: pharmacotherapies. Curr Probl Dermatol 45: 175-185.

47. Kim KH, Horn TD, Pharis J, Kincannon J, Jones R, et al. (2010) Phase 1 clinical trial of intralesional injection of Candida antigen for the treatment of warts. Arch Dermatol 146(12): 1431-1433.

48. Wilmer EN, Burkhart CN, Morrell DS (2013) Goodbye warts, hello vitiligo: Candida antigen-induced depigmentation. Pediatr Dermatol 30(6): e214-215.

49. Perman M, Sterling JB, Gaspari A (2005) The painful purple digit: an alarming complication of Candida albicans antigen treatment of recalcitrant warts. Dermat 16(1): 38-40.

50. Kollipara R, Ekhlassi E, Downing C, Guidry J, Lee M, et al. (2015) Advancements in Pharmacotherapy for Noncancerous Manifestations of HPV. J Clin Med 4(5): 832-846.

51. Pandey RK, Sodhi A, Biswas SK, Dahiya Y, Dhillon MK (2012) Mycobacterium indicus pranii mediates macrophage activation through TLR2 and NOD2 in a MyD88 dependent manner. Vaccine 30(39): 5748-5754.

52. Ahmad F, Mani J, Kumar P, Haridas S, Upadhyay P, et al. (2011) Activation of anti-tumor immune response and reduction of regulatory $\mathrm{T}$ cells with Mycobacterium indicus pranii (MIP) therapy in tumor bearing mice. PLoS One 6(9): e25424.

53. Banerjee S, Halder K, Ghosh S, Bose A, Majumdar S (2015) The combination of a novel immunomodulator with a regulatory $\mathrm{T}$ cell suppressing antibody (DTA-1) regress advanced stage B16F10 solid tumor by repolarizing tumor associated macrophages in situ. Oncoimmunology 4(3): e995559.

54. Rakshit S, Ponnusamy M, Papanna S, Saha B, Ahmed A, et al. (2012) Immunotherapeutic efficacy of Mycobacterium indicus pranii in eliciting anti-tumor T cell responses: critical roles of IFN $\gamma$. Int J Cancer 130(4): 865-875.

55. Kharkar R (2002) Immune recovery in HIV with Mycobacterium W. J Indian Med Assoc 100(9): 578-579.

56. Khamar B, O Donnell M, Belani PC (2012) Intradermal toll like receptor-2 (TLR2) agonist mycobacterium $w$ (Cadi-05) in the treatment of BCG refractory non muscle invasive transitional cell carcinoma of bladder. Journla of Immunotherapy.

57. Mosca PJ, Nair SG, Ayre SK, Wenjin Shi RN, Sherrine Edi, et al. (2010) Immunologic Therapy with Cadi-05 for the Treatment of Advanced Melanoma.

58. Khullar G, Narang T, De D, Nahar Saikia U, Dogra S, et al. (2017) Recalcitrant giant condyloma acuminatum treated successfully with a novel combination of Mycobacterium indicus pranii immunotherapy and acitretin. Int J STD AIDS 28(11): 1155-1157.

59. Sardana K, Goel K, Madan A, Garg VK (2016) Can We Predict the Effectiveness of Intralesional Immunotherapy in Recalcitrant Warts? Skinmed 14(6): 413-421. 


\section{Open Access Journal of Surgery}

60. Thappa DM, Chiramel MJ (2016) Evolving role of immunotherapy in the treatment of refractory warts. Indian Dermatol Online J 7(5): 364370 .

61. Dhakar AK, Dogra S, Vinay K, Sarangal R, Kanwar AJ, et al. (2016) Intralesional Mycobacterium w Vaccine Versus Cryotherapy in Treatment of Refractory Extragenital Warts: A Randomized, OpenLabel, Comparative Study. J Cutan Med Surg 20(2): 123-129.

62. Singh S, Chouhan K, Gupta S (2014) Intralesional immunotherapy with killed Mycobacterium indicus pranii vaccine for the treatment of extensive cutaneous warts. Indian J Dermatol Venereol Leprol 80(6) 509-514.

63. Garg S, Baveja S (2014) Intralesional immunotherapy for difficult to treat warts with Mycobacterium w vaccine. J Cutan Aesthetic Surg $7(4):$ 203-208.

64. Kumar P, Dar L, Saldiwal S, Varma S, Datt Upadhyay A, et al. (2014) Intralesional injection of Mycobacterium $w$ vaccine vs imiquimod, $5 \%$, cream in patients with anogenital warts: a randomized clinical trial JAMA Dermatol 150(10): 1072-1078.

65. Meena JK, Malhotra AK, Mathur DK, Mathur DC (2013) Intralesional immunotherapy with Mycobacterium $w$ vaccine in patients with multiple cutaneous warts: uncontrolled open study. JAMA Dermatol 149(2): 237-239.

66. Gupta S, Malhotra AK, Verma KK, Sharma VK (2008) Intralesional immunotherapy with killed Mycobacterium $\mathrm{w}$ vaccine for the treatment of ano-genital warts: an open label pilot study. J Eur Acad Dermatol Venereol 22(9): 1089-1093.

67. Smith SP, Baxendale HE, Sterling JC (2017) Clearance of recalcitrant warts in a patient with idiopathic immune deficiency following administration of the quadrivalent human papillomavirus vaccine (2017) Clin Exp Dermatol 42(3): 306-308.

68. Martín JM, Escandell I, Ayala D, Jordá E (2016) Spontaneous Remission of Recalcitrant Warts in Girls After Human Papillomavirus Vaccination. Actas Dermosifiliogr 107(6): 533-535.

69. Moscato GM, Di Matteo G, Ciotti M, Di Bonito P, Andreoni M, et al. (2016) Dual response to human papilloma virus vaccine in an immunodeficiency disorder: resolution of plantar warts and persistence of condylomas. J Eur Acad Dermatol Venereol 30(7): 12121213.

70. Abeck D, Fölster-Holst R (2015) Quadrivalent human papillomavirus vaccination: a promising treatment for recalcitrant cutaneous warts in children. Acta Derm Venereol 95(8): 1017-1019.

71. Landini MM, Borgogna C, Peretti A, Doorbar J, Griffin H, et al. (2015) Identification of the skin virome in a boy with widespread human papillomavirus-2-positive warts that completely regressed after administration of tetravalent human papillomavirus vaccine. $\mathrm{Br}$ Dermatol 173(2): 597-600.

72. Silling S, Wieland U, Werner M, Pfister H, Potthoff A, et al. (2014) Resolution of novel human papillomavirus-induced warts after HPV vaccination. Emerg Infect Dis 20(1): 142-145.

73. Daniel BS, Murrell DF (2013) Complete resolution of chronic multiple verruca vulgaris treated with quadrivalent human papillomavirus vaccine. JAMA Dermatol 149(3): 370-372.

74. Landis MN, Lookingbill DP, Sluzevich JC (2012) Recalcitrant plantar warts treated with recombinant quadrivalent human papillomavirus vaccine. J Am Acad Dermatol 67(2): e73-74.

75. Kreuter A, Waterboer T, Wieland U (2010) Regression of cutaneous warts in a patient with WILD syndrome following recombinant quadrivalent human papillomavirus vaccination. Arch Dermatol 146(10): 1196-1197.

76. Venugopal SS, Murrell DF (2010) Recalcitrant cutaneous warts treated with recombinant quadrivalent human papillomavirus vaccine (types
$6,11,16$, and 18 ) in a developmentally delayed, 31-year-old white man. Arch Dermatol 146(5): 475-477.

77. De Clercq E (2003) Clinical potential of the acyclic nucleoside phosphonates cidofovir, adefovir, and tenofovir in treatment of DNA virus and retrovirus infections. Clin Microbiol Rev 16(4): 569-596.

78. Stern PL, van der Burg SH, Hampson IN, Broker TR, Fiander A, et al. (2012) Therapy of human papillomavirus-related disease. Vaccine 30 Suppl 5: F71-82.

79. Amine A, Rivera S, Opolon P, Mehdi Dekkal, Biard SFD, et al. (2009) Novel anti-metastatic action of cidofovir mediated by inhibition of E6/ E7, CXCR4 and Rho/ROCK signaling in HPV tumor cells. PloS One 4(3): e5018.

80. Donne AJ, Hampson L, He XT, Day PJ, Salway F, et al. (2009) Potential risk factors associated with the use of cidofovir to treat benign human papillomavirus-related disease. Antivir Ther 14(7): 939-952.

81. Christensen ND, Pickel MD, Budgeon LR, Kreider JW (2000) In vivo antipapillomavirus activity of nucleoside analogues including cidofovir on CRPV-induced rabbit papillomas. Antiviral Res. 48(2): 131-142.

82. Christensen ND, Han R, Cladel NM, Pickel MD (2001) Combination treatment with intralesional cidofovir and viral-DNA vaccination cures large cottontail rabbit papillomavirus-induced papillomas and reduces recurrences. Antimicrob Agents Chemother 45(4): 1201-1209.

83. Padilla España L, Del Boz J, Fernández Morano T, Arenas Villafranca J, de Troya Martín M, et al. (2014) Topical cidofovir for plantar warts. Dermatol Ther 27(2): 89-93.

84. Padilla España L, Del Boz J, Fernández Morano T, Arenas-Villafranca J de Troya M, et al. (2014) Successful treatment of periungual warts with topical cidofovir. Dermatol Ther 27(6): 337-342.

85. Broganelli P, Chiaretta A, Fragnelli B, Bernengo MG (2012) Intralesional cidofovir for the treatment of multiple and recalcitrant cutaneous viral warts. Dermatol Ther 25(5): 468-471.

86. Henrickson SE, Treat JR (2017) Topical Cidofovir for Recalcitrant Verrucae in Individuals with Severe Combined Immunodeficiency After Hematopoietic Stem Cell Transplantation. Pediatr Dermatol 34(1): e24-e25.

87. Cleary A, Watson R, McMahon CJ (2014) Successful treatment of refractory cutaneous warts using topical 3\% cidofovir in a child after heart transplant. J Heart Lung Transplant 33(9): 971-972.

88. Fernández Morano T, Del Boz J, Frieyro Elichegui M, Repiso JB, Padilla España L, et al. (2013) [Treatment of anogenital warts with topical cidofovir]. Enferm Infecc Microbiol Clin 31(4): 222-226.

89. Gupta M, Bayliss SJ, Berk DR (2013) Topical cidofovir for refractory verrucae in children. Pediatr Dermatol 30(1): 131-134.

90. Fernández Morano T, del Boz J, González Carrascosa M, Tortajada B, de Troya M (2011) Topical cidofovir for viral warts in children. J Eur Acad Dermatol Venereol 25(12): 1487-1489.

91. Zabawski EJ, Sands B, Goetz D, Naylor M, Cockerell CJ, et al. (1997) Treatment of verruca vulgaris with topical cidofovir. JAMA 278(15): 1236.

92. Moore E, Kovarik C (2015) Intralesional cidofovir for the treatment of a plantar wart. J Am Acad Dermatol 73(1): e23-e24.

93. Blouin MM, Cloutier R, Noël R (2012) Intralesional cidofovir in the treatment of cutaneous warts in a renal transplant patient. J Cutan Med Surg 16(6): 462-464

94. Gormley RH, Kovarik CL (2012) Human papillomavirus-related genital disease in the immunocompromised host: Part II. J Am Acad Dermatol 66(6): 883.

95. Padilla España L, Del Boz J, Fernández-Morano T, Escudero-Santos I, Arenas-Villafranca J, et al. (2016) Recalcitrant warts and topical 


\section{Open Access Journal of Surgery}

cidofovir: predictive factors of good response. J Eur Acad Dermatol Venereol 30(7): 1218-1220.

96. Cha S, Johnston L, Natkunam Y, Brown J (2005) Treatment of verruca vulgaris with topical cidofovir in an immunocompromised patient: a case report and review of the literature. Transpl Infect Dis 7(3-4): 158161.

97. D’Souza GF, Zins JE (2017) Severe Plantar Warts in an Immunocompromised Patient. N Engl J Med 377(3): 267.

98. Nambudiri VE, Mutyambizi K, Walls AC, Fisher DC, Bleday R, et al. (2013) Successful treatment of perianal giant condyloma acuminatum in an immunocompromised host with systemic interleukin 2 and topical cidofovir. JAMA Dermatol 149(9): 1068-1070.

99. Loo SKF, Tang WYM (2015) Warts (non-genital). BMJ Clin Evid.

100. Bertolotti A, Dupin N, Bouscarat F, Milpied B, Derancourt C (2017) Cryotherapy to treat anogenital warts in nonimmunocompromised adults: Systematic review and meta-analysis. J Am Acad Dermatol $77(3):$ 518-526.

101. Kwok CS, Gibbs S, Bennett C, Holland R, Abbott R (2012) Topical treatments for cutaneous warts. Cochrane Database Syst Rev (9): CD001781.

102. Fathi R, Tsoukas MM (2014) Genital warts and other HPV infections: established and novel therapies. Clin Dermatol 32(2): 299-306.

103. Stone KM, Becker TM, Hadgu A, Kraus SJ (1990) Treatment of external genital warts: a randomised clinical trial comparing podophyllin, cryotherapy, and electrodesiccation. Genitourin Med 66(1): 16-19.

104. Godley MJ, Bradbeer CS, Gellan M, Thin RN (1987) Cryotherapy compared with trichloroacetic acid in treating genital warts. Genitourin Med 63(6): 390-392.

105. Handley JM, Maw RD, Horner T, Lawther H, McNeill T, et al. (1992) Non-specific immunity in patients with primary anogenital warts treated with interferon alpha plus cryotherapy or cryotherapy alone. Acta Derm Venereol 72(1): 39-40.

106. Bruggink SC, Gussekloo J, Berger MY, Zaaijer K, Assendelft WJ, et al. (2010) Cryotherapy with liquid nitrogen versus topical salicylic acid application for cutaneous warts in primary care: randomized controlled trial. CMAJ 182(15): 1624-1630.

107. Duus BR, Philipsen T, Christensen JD, Lundvall F, Søndergaard J (1985) Refractory condylomata acuminata: a controlled clinica trial of carbon dioxide laser versus conventional surgical treatment. Genitourin Med 61(1): 59-61.

108. Khawaja HT (1989) Podophyllin versus scissor excision in the treatment of perianal condylomata acuminata: a prospective study. Br J Surg 76(10): 1067-1068.

109. Jensen SL (1985) Comparison of podophyllin application with simple surgical excision in clearance and recurrence of perianal condylomata acuminata. Lancet 2(8465): 1146-1148.

110. Bellina JH (1983) The use of the carbon dioxide laser in the management of condyloma acuminatum with eight-year follow-up. American Journal of obstetrics \& Gynecology 147(4): 375-378.

111. Garden JM, O’Banion MK, Shelnitz LS, Pinski KS, Bakus AD, et al (1988) Papillomavirus in the vapor of carbon dioxide laser-treated verrucae. JAMA 259(8): 1199-1202.

112. Badawi A, Shokeir HA, Salem AM, Soliman M, Fawzy S, et al. (2002) Treatment of anogenital warts by pulsed dye laser. J Cosmet Laser Ther 28(4): 350-352.

113. Logan RA, Zachary CB (1989) Outcome of carbon dioxide laser therapy for persistent cutaneous viral warts. Br J Dermatol 121(1): 99-105.
114. Hruza GJ (1997) Laser treatment of warts and other epidermal and dermal lesions. Dermatol Clin 15(3): 487-506.

115. Ozluer SM, Chuen BY, Barlow RJ, Markey AC (2001) Hypertrophic scar formation following carbon dioxide laser ablation of plantar warts in cyclosporin-treated patients. Br J Dermatol 145(6): 10051007.

116. Robson KJ, Cunningham NM, Kruzan KL, Patel DS, Kreiter CD, et al. (2000) Pulsed-dye laser versus conventional therapy in the treatment of warts: a prospective randomized trial. J Am Acad Dermatol 43(2 Pt 1): $275-280$.

117. Sparreboom EE, Luijks HG, Luiting Welkenhuyzen HA, Willems PW Groeneveld CP, et al. (2014) Pulsed dye laser treatment is effective in the treatment of recalcitrant viral warts. Dermatol Surg off Publ Am Soc Dermatol 34(1): 67-72.

118. Sterling JC, Gibbs S, Haque Hussain SS, Mohd Mustapa MF, Handfield Jones SE (2014) British Association of Dermatologists' guidelines for the management of cutaneous warts 2014. Br J Dermatol 171(4): 696-712.

119. Tan OT, Hurwitz RM, Stafford TJ (1993) Pulsed dye laser treatment of recalcitrant verrucae: a preliminary report. Lasers Surg Med 13(1): 127-137.

120. Kenton Smith J, Tan ST (1999) Pulsed dye laser therapy for viral warts. Br J Plast Surg 52(7): 554-558.

121. Vargas H, Hove CR, Dupree ML, Williams EF (2002) The treatment of facial verrucae with the pulsed dye laser. The Laryngoscope 112(9): 1573-1576.

122. Akhyani M, Ehsani A, Noormohammadpour P, Roghieh Shamsodini Sahar Azizahari, et al. (2011) Comparing Pulsed-dye Laser with Cryotherapy in the Treatment of Common Warts. Journal of Lasers in Medical Sciences 1(1): 14-19.

123. Nguyen J, Korta DZ, Chapman LW, Kelly KM (2016) Laser Treatment of Nongenital Verrucae: A Systematic Review. JAMA Dermatol 152(9): 1025-1034.

124. Park HS, Choi WS (2008) Pulsed dye laser treatment for viral warts: a study of 120 patients. J Dermatol 35(8): 491-498.

125. Ross BS, Levine VJ, Nehal K, Tse Y, Ashinoff R, et al. (1999) Pulsed dye laser treatment of warts: an update. Dermatol Surg 25(5): 377-380.

126. Sethuraman G, Richards KA, Hiremagalore RN, Wagner A (2010) Effectiveness of pulsed dye laser in the treatment of recalcitrant warts in children. Dermatol Surg 36(1): 58-65.

127. Pollock B, Sheehan Dare R (2002) Pulsed dye laser and intralesional bleomycin for treatment of resistant viol hand warts. Lasers Surg Med 30(2): 135-140.

128. Karrer S, Bosserhoff AK, Weiderer P, Landthaler M, Szeimies RM (2004) Keratinocyte-derived cytokines after photodynamic therapy and their paracrine induction of matrix metalloproteinases in fibroblasts. Br J Dermatol 151(4): 776-783.

129. Giomi B, Pagnini F, Cappuccini A, Bianchi B, Tiradritti L, et al. (2011) Immunological activity of photodynamic therapy for genital warts. Br J Dermatol 164(2): 448-451.

130. Bu ZY, Yu XH, Wu LM, Zhong JB, Yang P, et al. (2017) Normalization of regulatory T cells, serum TGF- $\beta 1$, and LTN after 5-aminolevulinic acid-photodynamic therapy in patients with condyloma acuminate. Exp Ther Med 13(6): 3327-3332.

131. Kim JE, Kim SJ, Hwang JI, Lee KJ, Park HJ, et al. (2012) New proposal for the treatment of viral warts with intralesional injection of 5-aminolevulinic acid photodynamic therapy. J Dermatolog Treat 23(3): 192-195. 
132. Li X, Wang X, Gu J, Ma Y, Liu Z, et al. (2013) Needle-free injection of 5-aminolevulinic acid in photodynamic therapy for the treatment of condylomata acuminata. Exp Ther Med 6(1): 236-240.

133. Lee Y, Baron ED (2011) Photodynamic therapy: current evidence and applications in dermatology. Semin Cutan Med Surg 30(4): 199-209.

134. Caucanas M, Gillard P, Vanhooteghem O (2010) Efficiency of photodynamic therapy in the treatment of diffuse facial viral warts in an immunosuppressed patient: towards a gold standard? Case Rep Dermatol 2(3): 207-213.

135. Kim M, Jung HY, Park HJ (2015) Topical PDT in the Treatment of Benign Skin Diseases: Principles and New Applications. Int J Mol Sci 16(10): 23259-23278.

136. Mizuki D, Kaneko T, Hanada K (2003) Successful treatment of topical photodynamic therapy using 5-aminolevulinic acid for plane warts. Br J Dermatol 149(5): 1087-1088.

137. Lu YG, Wu JJ, He Y, Yang HZ, Yang YD (2010) Efficacy of topical aminolevulinic acid photodynamic therapy for the treatment of verruca planae. Photomed Laser Surg 28(4): 561-563.

138. Wang XL, Wang HW, Wang HS, Xu SZ, Liao KH, et al. (2004) Topical 5-aminolaevulinic acid-photodynamic therapy for the treatment of urethral condylomata acuminata. Br J Dermatol 151(4): 880-885.

139. Liang J, Lu XN, Tang H, Zhang Z, Fan J, et al. (2009) Evaluation of photodynamic therapy using topical aminolevulinic acid hydrochloride in the treatment of condylomata acuminata: a comparative, randomized clinical trial. Photodermatol Photoimmunol Photomed 25(6): 293-297.

140. Stender IM, Lock Andersen J, Wulf HC (1999) Recalcitrant hand and foot warts successfully treated with photodynamic therapy with topical 5-aminolaevulinic acid: a pilot study. Clin Exp Dermatol 24(3): 154-159.

141. Szeimies RM, Schleyer V, Moll I, Stocker M, Landthaler M, et al. (2009) Adjuvant photodynamic therapy does not prevent recurrence of condylomata acuminata after carbon dioxide laser ablation-A phase III, prospective, randomized, bicentric, double-blind study. Dermatol Surg 35(5): 757-764.

142. Stender IM, Na R, Fogh H, Gluud C, Wulf HC (2000) Photodynamic therapy with 5-aminolaevulinic acid or placebo for recalcitrant foot and hand warts: randomised double-blind trial. Lancet 355(9208): 963-966.

143. Nucci V, Torchia D, Cappugi P (2010) Treatment of anogenital condylomata acuminata with topical photodynamic therapy: report of 14 cases and review. Int J Infect Dis 14 Suppl 3: e280-e282.

144. Lacey CJN, Woodhall SC, Wikstrom A, Ross J (2013) European guideline for the management of anogenital warts. J Eur Acad Dermatol Venereol 27(3): e263-e270.

145. Arican O, Guneri F, Bilgic K, Karaoglu A (2004) Topical imiquimod $5 \%$ cream in external anogenital warts: a randomized, double-blind, placebo-controlled study. J Dermatol 31(8): 627-631.

146. Kreuter A, Potthoff A, Brockmeyer NH, Gambichler T, Stücker M, et al. (2008) et al. Imiquimod leads to a decrease of human papillomavirus DNA and to a sustained clearance of anal intraepithelial neoplasia in HIV-infected men. J Invest Dermatol 128(8): 2078-2083.

147. van Poelgeest MI, van Seters $M$, van Beurden $M$, Kwappenberg KM, Heijmans Antonissen C, et al. (2005) Detection of human papillomavirus (HPV) 16 specific CD4+ T-cell immunity in patients with persistent HPV16-induced vulvar intraepithelial neoplasia in relation to clinical impact of imiquimod treatment. Clin Cancer Res 11(14): 5273-5280.

148. Winters U, Daayana S, Lear JT, Tomlinson AE, Elkord E, et al. (2008)
Clinical and immunologic results of a phase II trial of sequential imiquimod and photodynamic therapy for vulval intraepithelial neoplasia. Clin Cancer Res 14(16): 5292-5299.

149. Komericki P, Akkilic Materna M, Strimitzer T, Aberer W (2011) Efficacy and safety of imiquimod versus podophyllotoxin in the treatment of anogenital warts. Sex Transm Dis 38(3): 216-218.

150. Beutner KR, Tyring SK, Trofatter KF, Douglas JM, Spruance S, et al. (1998) Imiquimod, a patient-applied immune-response modifier for treatment of external genital warts. Antimicrob Agents Chemother 42(4): 789-794.

151. Beutner KR, Spruance SL, Hougham AJ, Fox TL, Owens ML, et al (1998) Treatment of genital warts with an immune-response modifier (imiquimod). J Am Acad Dermatol 38(2 Pt 1): 230-239.

152. Edwards L, Ferenczy A, Eron L, Baker D, Owens ML, et al. (1998) Selfadministered topical 5\% imiquimod cream for external anogenital warts. HPV Study Group. Human Papilloma Virus. Arch Dermatol 134(1): 25-30.

153. Fife KH, Ferenczy A, Douglas JM, Brown DR, Smith M, et al. (2001) Treatment of external genital warts in men using $5 \%$ imiquimod cream applied three times a week, once daily, twice daily, or three times a day. Sex Transm Dis 28(4): 226-231.

154. Garland SM, Waddell R, Mindel A, Denham IM, McCloskey JC (2006) An open-label phase II pilot study investigating the optimal duration of imiquimod $5 \%$ cream for the treatment of external genital warts in women. Int J STD AIDS 17(7): 448-452.

155. Schöfer H, Van Ophoven A, Henke U, Lenz T, Eul A (2006) Randomized, comparative trial on the sustained efficacy of topical imiquimod 5\% cream versus conventional ablative methods in external anogenital warts. Eur J Dermatol 16(6): 642-648.

156. Hengge UR, Esser S, Schultewolter T, Behrendt C, Meyer T, et al. (2000) Self-administered topical 5\% imiquimod for the treatment of common warts and molluscum contagiosum. Br J Dermatol 143(5): 1026-1031

157. Smith WA, Siegel D, Lyon VB, Holland KE (2013) Psoriasiform eruption and oral ulcerations as adverse effects of topical $5 \%$ imiquimod treatment in children: a report of four cases. Pediatr Dermatol 30(6): e157-e160.

158. Rosenblatt A, de Campos Guidi HG (2012) Local and systemic adverse effects of imiquimod therapy for external anogenital warts in men: report of three cases. Int J STD AIDS 23(12): 909-910.

159. Zeng Y, Zheng YQ Wang L (2014) Vagarious successful treatment of recalcitrant warts in combination with $\mathrm{CO} 2$ laser and imiquimod 5\% cream. J Cosmet Laser Ther 16(6): 311-313.

160. Hoyme UB, Hagedorn M, Schindler AE, Schneede P, Hopfenmüller W, et al. (2002) Effect of adjuvant imiquimod 5\% cream on sustained clearance of anogenital warts following laser treatment. Infect Dis Obstet Gynecol 10(2): 79-88.

161. Park SM, Kim GW, Mun JH, Song M, Kim HS, et al. Fractional LaserAssisted Topical Imiquimod 5\% Cream Treatment for Recalcitrant Common Warts in Children: A Pilot Study. Dermatol Surg 42(12): $1340-1346$

162. Viazis N, Vlachogiannakos J, Vasiliadis K, Theodoropoulos I Saveriadis A, et al. (2007) Earlier eradication of intra-anal warts with argon plasma coagulator combined with imiquimod cream compared with argon plasma coagulator alone: a prospective, randomized trial. Dis Colon Rectum 50(12): 2173-2179.

163. Housman TS, Jorizzo JL (2002) Anecdotal reports of 3 cases illustrating a spectrum of resistant common warts treated with cryotherapy followed by topical imiquimod and salicylic acid. J Am 
Acad Dermatol 47(4 Suppl): S217-220.

164. Tucker SB, Ali A, Ransdell BL (2003) Plantar wart treatment with combination imiquimod and salicylic acid pads. J Drugs Dermatol 2(2): 124-126.

165. Tyring SK (2012) Effect of Sinecatechins on HPV-Activated Cell Growth and Induction of Apoptosis. J Clin Aesthetic Dermatol 5(2): 34-41.

166. Nguyen HP, Doan HQ Rady P, Tyring SK (2015) Cellular signaling in sinecatechins-treated external genital and perianal warts: unraveling the mechanism of action of a botanical therapy. Virol Sin 30(3): 214217.

167. Harrison Nguyen, Hung Q Doan, David J Brunell, Peter L Rady, Stephen Keith Tyring (2014) Apoptotic gene expression in sinecatechinstreated external genital and perianal warts. Viral Immunol 27(10): 556-558.

168. Doan HQ Nguyen HP, Rady P, Tyring SK (2015) Expression patterns of immune-associated genes in external genital and perianal warts treated with sinecatechins. Viral Immunol 28(4): 236-240.

169. Tyring SK (2012) Sinecatechins: Effects on HPV-Induced Enzymes Involved in Inflammatory Mediator Generation. J Clin Aesthetic Dermatol 5(1): 19-26.

170. Tzellos TG, Sardeli C, Lallas A, Papazisis G, Chourdakis M, et al. (2011) Efficacy, safety and tolerability of green tea catechins in the treatment of external anogenital warts: a systematic review and meta-analysis. J Eur Acad Dermatol Venereol 25(3): 345-353.

171. Gross G, Meyer KG, Pres H, Thielert C, Tawfik H, et al. (2007) A randomized, double-blind, four-arm parallel-group, placebocontrolled Phase II/III study to investigate the clinical efficacy of two galenic formulations of Polyphenon $\mathrm{E}$ in the treatment of external genital warts. J Eur Acad Dermatol Venereol 21(10): 1404-1412.

172. Stockfleth E, Beti H, Orasan R, Grigorian F, Mescheder A, et al. (2008) Topical Polyphenon $\mathrm{E}$ in the treatment of external genital and perianal warts: a randomized controlled trial. Br J Dermatol 158(6): 1329-1338.

173. Tatti S, Swinehart JM, Thielert C, Tawfik H, Mescheder A, et al (2008) Sinecatechins, a defined green tea extract, in the treatment of external anogenital warts: a randomized controlled trial. Obstet Gynecol 111(6): 1371-1379.

174. Tatti S, Stockfleth E, Beutner KR, Tawfik H, Elsasser U, et al. (2010) Polyphenon E: a new treatment for external anogenital warts. Br J Dermatol 162(1): 176-184.

175. On SC, Linkner RV, Haddican M, Yaroshinsky A, Gagliotti M, et al (2014) A single-blinded randomized controlled study to assess the efficacy of twice daily application of sinecatechins $15 \%$ ointment when used sequentially with cryotherapy in the treatment of external genital warts. J Drugs Dermatol 13(11): 1400-1405.

176. Juhl ME, Seferovic V, Antonijevic S, Krunic A (2016) Combined treatment of anogenital HPV infection with cryodestruction, podophyllin $25 \%$ and post-ablation immunomodulation with sinecatechins $15 \%$ ointment-a retrospective analysis. Int J STD AIDS 27(12): 1071-1078.
177. Faluhelyi Z, Rodler I, Csejtey A, Tyring SK, Ember IA, et al. (2004) All-trans retinoic acid (ATRA) suppresses transcription of human papillomavirus type 16 (HPV16) in a dose-dependent manner. Anticancer Res 24(2B): 807-809.

178. Olguin García MG, Jurado Santa Cruz F, Peralta Pedrero ML, Morales Sánchez MA (2015) A double-blind, randomized, placebo-controlled trial of oral isotretinoin in the treatment of recalcitrant facial flat warts. J Dermatol Treat 26(1): 78-82.

179. Monastirli A, Matsouka P, Pasmatzi E, Melachrinou M, Georgiou S, et al. (2005) Complete remission of recalcitrant viral warts under oral isotretinoin in a patient with low-grade B-cell lymphoma. Acta Derm Venereol 85(4): 358-360.

180. Katz RA (1986) Isotretinoin treatment of recalcitrant warts in an immunosuppressed man. Arch Dermatol 122(1): 19-20.

181. Kaur GJ, Brar BK, Kumar S, Brar SK, Singh B (2017) Evaluation of the efficacy and safety of oral isotretinoin versus topical isotretinoin in the treatment of plane warts: a randomized open trial. Int J Dermatol 56(12): 1352-1358.

182. Miljkovic J (2012) A novel therapeutic approach to plane warts: a report on two cases. Acta Dermatovenerol Alp Pannonica Adriat 21(3): 63-64.

183. Al Hamamy HR, Salman HA, Abdulsattar NA (2012) Treatment of plane warts with a low-dose oral isotretinoin. ISRN Dermatology 2012(2012): 1-3.

184. Georgala S, Katoulis AC, Georgala C, Bozi E, Mortakis A (2004) Oral isotretinoin in the treatment of recalcitrant condylomata acuminata of the cervix: a randomised placebo controlled trial. Sex Transm Infect 80(3): 216-218.

185. Tsambaos D, Georgiou S, Monastirli A, Sakkis T, Sagriotis A, et al. (1997) Treatment of condylomata acuminata with oral isotretinoin. J Urol 158(5): 1810-1812.

186. Cardamakis EK, Kotoulas IG, Dimopoulos DP, Stathopoulos EN, Michopoulos JT, et al. (1996) Comparative study of systemic interferon alfa-2a with oral isotretinoin and oral isotretinoin alone in the treatment of recurrent condylomata accuminata. Arch Gynecol Obstet 258(1): 35-41.

187. Jha AK, Sonthalia S, Ganguly S (2018) Oral isotretinoin as an adjunctive treatment for recurrent genital warts. J Am Acad Dermatol 78(2): e35-e36.

188. Yew YW, Pan JY (2014) Complete remission of recalcitrant genital warts with a combination approach of surgical debulking and oral isotretinoin in a patient with systemic lupus erythematosus. Dermatol Ther 27(2): 79-82.

189. Cao Y, Zhao J, Yang Z, Cai Z, Zhang B, et al. (2010) CD4+FOXP3+ regulatory $\mathrm{T}$ cell depletion by low-dose cyclophosphamide prevents recurrence in patients with large condylomata acuminata after laser therapy. Clin Immunol 136(1): 21-29.

190. Zhang Y, Duan Y, Zhao J, Huang B, Cao YC (2013) Low-dose oral cyclophosphamide therapy is effective for condylomata acuminata. Chin Med J (Engl) 126(16): 3198-3199. 
$\Theta$

This work is licensed under Creative Commons Attribution 4.0 License DOI:_10.19080/OAJS.2018.09.555752

\section{Your next submission with Juniper Publishers} will reach you the below assets

- Quality Editorial service

- Swift Peer Review

- Reprints availability

- E-prints Service

- Manuscript Podcast for convenient understanding

- Global attainment for your research

- Manuscript accessibility in different formats

( Pdf, E-pub, Full Text, Audio)

- Unceasing customer service

Track the below URL for one-step submission https://juniperpublishers.com/online-submission.php 